Supplement of The Cryosphere, 12, 1551-1562, 2018

https://doi.org/10.5194/tc-12-1551-2018-supplement

(C) Author(s) 2018. This work is distributed under

the Creative Commons Attribution 4.0 License.

(c) (1)

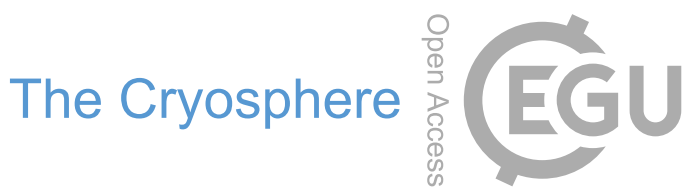

Supplement of

\title{
A new digital elevation model of Antarctica derived from CryoSat-2 altimetry
}

Thomas Slater et al.

Correspondence to: Thomas Slater (py10ts@leeds.ac.uk)

The copyright of individual parts of the supplement might differ from the CC BY 4.0 License. 


\section{Elevation retrieval from CryoSat-2: data filtering approach}

After the application of Eq. (1) to our selected CryoSat-2 dataset, we apply a series of quality filters to remove unrealistic elevation estimates from poorly constrained model fits. In order to identify these unrealistic elevation estimates, we introduce constraints based upon (i) data availability, (ii) data quality and (iii) physical plausibility (Table S1). Controls on data availability include a minimum number of data points, and length of the elevation time series within each grid cell. In each case, threshold values have been tested and found to be optimal. A minimum of 15 data points, and time series length of at least 2 years ensures that each model fit is constrained by sufficient data. We remove poorly constrained fits by introducing thresholds on the goodness of fit, with maximum values of the root mean squared difference of the elevation residuals from the model fit, and 1-sigma uncertainty in the elevation rate being $10 \mathrm{~m}$ and $0.4 \mathrm{~m} \mathrm{yr}^{-1}$, respectively. Finally, we remove any estimates that are not physically plausible. Maximum rates of elevation change have been reported to be $9 \mathrm{~m} \mathrm{yr}^{-1}$ in Antarctica (McMillan et al., 2014), so we remove any elevation rate estimate with a magnitude exceeding $10 \mathrm{~m} \mathrm{yr}^{-1}$. In addition, we impose a maximum quadratic surface slope value of $5^{\circ}$ to maintain physically plausible glacier driving stresses - averaged over the grid cell resolution - which are controlled by the slope.

After data filtering, the model fit provides an elevation estimate for $60 \%, 91 \%$ and $94 \%$ of grid cells within the Antarctic ice sheet at resolutions of $1 \mathrm{~km}, 2 \mathrm{~km}$ and $5 \mathrm{~km}$, respectively. For the Antarctic ice shelves, $75 \%$ and $98 \%$ of grid cells at resolutions of $1 \mathrm{~km}$ and $2 \mathrm{~km}$, respectively, contain an elevation estimate from our model fit approach after quality filtering has been applied.

Table S1. Selection criteria used to remove elevation estimates resulting from poorly constrained model fits.

\begin{tabular}{cc}
\hline Parameter & Selection criteria \\
\hline Number of data points & $\leq 15$ \\
Time series length (yrs) & $\leq 2$ \\
Root mean squared difference of elevation residuals from model fit $(\mathrm{m})$ & $\geq 10$ \\
1-sigma uncertainty in dh/dt $\left(\mathrm{m} \mathrm{yr}^{-1}\right)$ & $\geq 0.4$ \\
${\text { dh/dt }\left(\mathrm{m} \mathrm{yr}^{-1}\right)}^{\text {Surface slope }\left({ }^{\circ}\right)}$ & $\geq 10$ \\
& $\geq 5$ \\
\hline
\end{tabular}

\section{Backscatter correction to elevation change time series}

We correct for temporally correlated fluctuations in changes in elevation and radar backscatter, known to introduce spurious signals in time series of elevation obtained using satellite radar altimetry (Wingham et al., 1998; Davis and Ferguson, 2004; Khvorostovsky, 2012). To apply this correction (Eq. (S1)), we first compute the correlation gradient in elevation as a function of power, $\frac{d h}{d p}$, using a linear fit in each grid cell over a 60-month time window. We then multiply time series of changes in backscattered power $d p$ by this gradient to estimate the backscatter correction term, which we remove from our original elevation change time series $d h$.

$$
d h_{\text {corrected }}=d h-\left(d p \frac{d h}{d p}\right)
$$




\section{DEM difference maps}

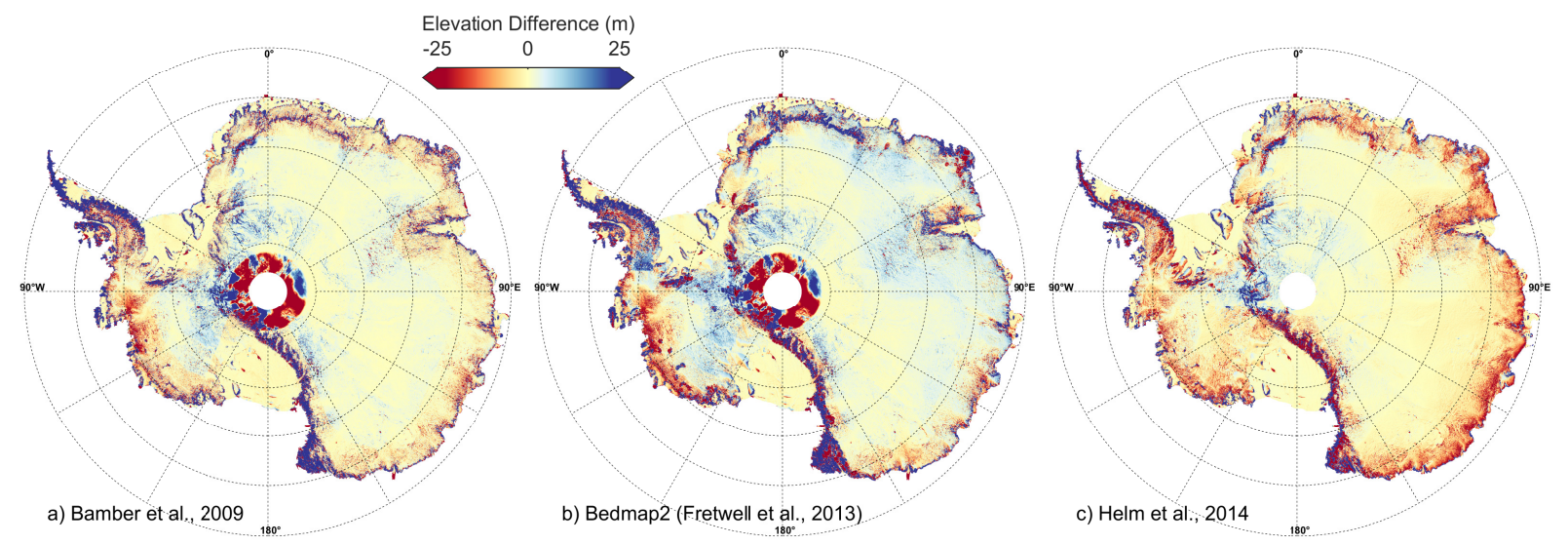

Figure S1. Maps of differences calculated between the new CryoSat-2 DEM described in this manuscript, and the three publicly available DEMs used in Figure 8 (Bamber et al., 2009; Fretwell et al,. 2013; Helm et al., 2014). In each case the previously published DEM is resampled to the posting of the new CryoSat-2 DEM, and differences calculated as the resampled DEM subtracted from the new CryoSat-2 DEM. 


\section{Product format}

- DEM and supplementary grids (slope, grid cell data composition, uncertainty, smoothed DEM) available in netcdf and geotiff formats

- Projection: Polar Stereographic

- Ellipsoid: WGS-84

- Standard latitude: $-71^{\circ}$

- Central meridian: $0^{\circ}$

- Minimum x value: $-2819500 \mathrm{~m}$

- Minimum y value: $-2419500 \mathrm{~m}$

- Grid spacing: $1000 \mathrm{~m}$

- Coordinate convention: Grid coordinate values relate to the centre of each grid cell

- Number of rows: 4840

- Number of columns: 5640

- DEM units: metres

- Data format: big-endian IEEE 4-byte floating point format, no data value is $\mathrm{NaN}$ 


\section{References}

Bamber, J. L., Gomez-Dans, J. L., and Griggs, J. A.: A new digital elevation model of the Antarctic derived from combined satellite radar and laser data - Part 1: Data and methods, The Cryosphere, 3, 101-111, doi:10.5194/tc-3-101-2009, 2009.

Davis, C. H. and Ferguson, A. C.: Elevation change of the Antarctic ice sheet, 1995-2000, from ERS-2 satellite radar altimetry, IEEE T. Geosci. Remote, 42, 2437-2445, doi:10.1109/TGRS.2004.836789, 2004.

Fretwell, P., Pritchard, H. D., Vaughan, D. G., Bamber, J. L., Barrand, N. E., Bell, R., Bianchi, C., Bingham, R. G., Blankenship, D. D., Casassa, G., Catania, G., Callens, D., Conway, H., Cook, A. J., Corr, H. F. J., Damaske, D., Damm, V., Ferraccioli, F., Forsberg, R., Fujita, S., Gim, Y., Gogineni, P., Griggs, J. A., Hindmarsh, R. C. A., Holmlund, P., Holt, J. W., Jacobel, R. W., Jenkins, A., Jokat, W., Jordan, T., King, E. C., Kohler, J., Krabill, W., Riger-Kusk, M., Langley, K. A., Leitchenkov, G., Leuschen, C., Luyendyk, B. P., Matsuoka, K., Mouginot, J., Nitsche, F. O., Nogi, Y., Nost, O. A., Popov, S. V., Rignot, E., Rippin, D. M., Rivera, A., Roberts, J., Ross, N., Siegert, M. J., Smith, A. M., Steinhage, D., Studinger, M., Sun, B., Tinto, B. K., Welch, B. C., Wilson, D., Young, D. A., Xiangbin, C., and Zirizzotti, A.: Bedmap2: improved ice bed, surface and thickness datasets for Antarctica, The Cryosphere, 7, 375-393, doi:10.5194/tc-7-375-2013, 2013.

Helm, V., Humbert, A., and Miller, H.: Elevation and elevation change of Greenland and Antarctica derived from CryoSat-2, The Cryosphere, 8, 1539-1559, doi:10.5194/tc-8-1539-2014, 2014.

Khvorostovsky, K.S.: Merging and analysis of elevation time series over Greenland ice sheet from satellite radar altimetry, IEEE T. Geosci. Remote, 50, 23-36, doi:10.1109/TGRS.2011.2160071, 2012.

McMillan, M., Shepherd, A., Sundal, A., Briggs, K., Muir, A., Ridout, A., Hogg, A., and Wingham, D.: Increased ice losses from Antarctica detected by CryoSat-2, Geophys. Res. Lett., 41, 3899-3905, doi:10.1002/2014GL060111, 2014GL060111, 2014.

Wingham, D. J., Ridout, A. J., Scharroo, R., Arthern, R. J., and Shum, C. K.: Antarctic Elevation Change from 1992 to 1996, Science, 282, 456-458, doi:10.1126/science.282.5388.456, 1998. 